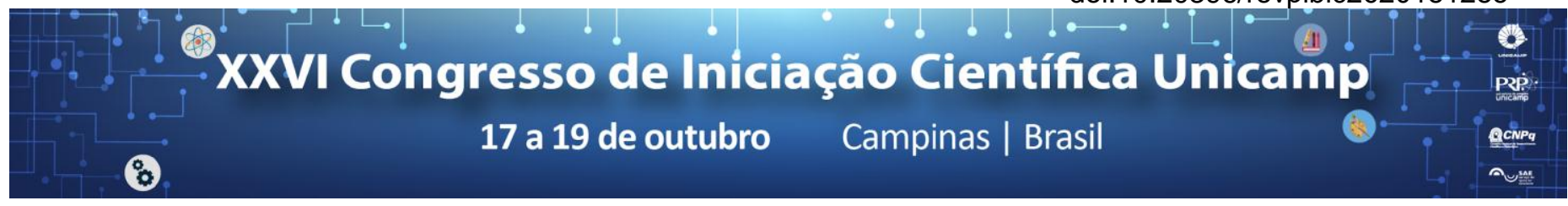

\title{
Use of X-ray microtomography for analysis of whole plant regeneration in Passiflora organensis
}

\section{Tatiane Yamaguchi Quijada*, Marcelo Carnier Dornelas.}

\begin{abstract}
$P$. organensis is a native species in Brazil and the first species of the genus Passiflora to have its genome completely sequenced. The present work intends to elaborate an efficient protocol for in vitro regeneration of whole plants of $P$. organensis through tissue culture and the implementation of an innovative technology of 3D image acquisition - the computerized X-ray microtomography (micro-CT).
\end{abstract}

\section{Key words:}

Passiflora organensis, tissue culture, micro-CT.

\section{Introduction}

$P$. organensis is becoming more relevant since it is the first species of the genus Passiflora to have its genome completely sequenced (data not yet published from our group). The study of gene functions, resulting from the sequencing of the genome of a plant, implicates the application of transgenesis techniques. However, in vitro plant regeneration protocols needs to be optimized, especially for this species, since none was established yet $^{1}$. This present work aims to establish efficient protocols of regeneration of whole plants, from leaf and internode explants, besides testing the effect of different concentrations of the hormones Auxin (NAA) and Cytokinin (BAP), as well the effect of coconut water in the tissue culture media.

In addition, another aim of this work is the implementation of an innovative technology of 3D image acquisition - the computerized X-Ray microtomography (micro-CT) - which will allow a more refined description of the morphogenetic processes during in vitro tissue culture ${ }^{2}$.

\section{Results and Discussion}

Preliminary results using leaf explant have shown better regeneration of P.organensis in media supplemented with $0,1 \mathrm{mg} \mathrm{I}^{-1}$ NAA and $10,0 \mathrm{mg} \mathrm{|}^{-1}$ BAP (Image 1). Concentrations above $0,1 \mathrm{mg} \mathrm{I}^{-1}$ NAA were inefficient, inhibited the regeneration of whole plants since high levels of auxin shown to be harmful .

When the coconut water was added in culture media, the calli were bigger.

The micro-CT technique is being implemented and the morphogenesis processes are being analyzed.

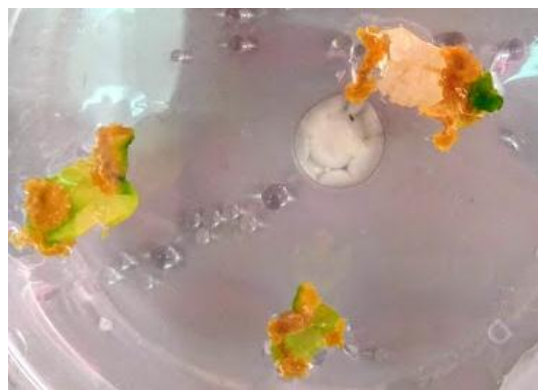

Image 1. Regeneration of $P$. organensis through tissue culture using $0,1 \mathrm{mg} \mathrm{I}^{-1} \mathrm{NAA}$ and $10,0 \mathrm{mg} \mathrm{I}^{-1}$ BAP after 93 days of culture.

\section{Conclusions}

Culture media supplemented with $0,1 \mathrm{mg} \mathrm{I}^{-1} \mathrm{NAA}$ and 10,0 $\mathrm{mg} \mathrm{I}^{-1}$ BAP and $10 \%$ coconut water, showed better results for leaf explants and may be useful for the establishment of an efficient protocol for the regeneration of whole plants of $P$. organensis.

\section{Acknowledgement}

The authors acknowledge Fundação de Amparo à Pesquisa do Estado de São Paulo (FAPESP) for financial support. Also, we would like to thank MSc Tatiana de Souza Moraes from Centro de Energia Nuclear na Agricultura (CENA) for the donation of plants of $P$. organensis in vitro, and Ms Jusceley Fátima P. Oliveira for technical assistance.

\footnotetext{
${ }^{1}$ Rosa, Y. B C J., Monte-Bello, C. C. \& Dornelas, M. C. Plant Cell Tissue Organ Cult. 2015, 120:69-77.

${ }^{2}$ Lee, K. J .I.; Calder, M. G., Hindle, C. R., Newman, J. L.., Robinson, S. N., Avondo, J. J. H. Y. \& Coen, E. S. Journal of Experimental Botany, 2017, 68: 527-538.
} 